\title{
The Supply of Inputs to Rice Farmers in Savannakhet
}

\section{Chitpasong Kousonsavath and Silinthone Sacklokham}

\section{INTRODUCTION}

The policy of rice intensification in Laos is dependent on an adequate supply of key inputs such as high-yielding seeds, good-quality fertilizers, reliable irrigation, affordable finance, and appropriate information. The study reported in this chapter focused on two crucial inputs for increased productivity in rice-seeds and fertilizers. The main objectives are to (a) map the seed and fertilizer supply chains; (b) identify the key actors in each chain and their roles; (c) identify major problems affecting the performance of each chain; and (d) provide recommendations for improvements in input supply.

Six villages in Champhone District, Savannakhet Province, were selected, as described in Chap. 7. Two villages (Phalaeng and Piakha) produced rice

C. Kousonsavath $(\bowtie)$

Faculty of Agriculture, Department of Rural Economics and Food Technology, National University of Laos, Vientiane, Laos

S. Sacklokham

SEAMEO Regional Centre for Community Education Development, Vientiane, Laos e-mail: s.sacklokham@nuol.edu.la

(C) The Author(s) 2020

R. Cramb (ed.), White Gold: The Commercialisation of Rice

Farming in the Lower Mekong Basin, https://doi.org/10.1007/978-981-15-0998-8_8 
Table 8.1 Number of interviewees by type of actor

\begin{tabular}{lc}
\hline Type of actor & No. interviewed \\
\hline Farmers & 228 \\
Vietnamese traders & 1 \\
Fertilizer import companies & 2 \\
Fertilizer shops & 8 \\
Rice millers & 3 \\
Thasano Seed Production Centre & 1 \\
Rice Production Improvement Project & 1 \\
Individual villagers & 1 \\
Individual suppliers & 5 \\
\hline
\end{tabular}

primarily for commercial purposes, two (Buekthong and Dondaeng) produced rice primarily for family consumption but regularly sold a surplus, and two (Khamsida and Khaokad) produced rice only for self-sufficiency. A preliminary survey was conducted to determine the broad picture of the seed and fertilizer supply chains in the six villages and to identify the key actors in each chain. This provided the basis for selecting interviewees in the second visit in March 2012. The types and numbers of interviewees are listed in Table 8.1. The farmers were selected randomly from the list of farmers in each village, including farmers who were members of a seed production group or involved in the government's Rice Production Improvement Project (RPIP).

\section{The Fertilizer Supply Chain}

As shown in Chap. 7 , most rice farmers $(85 \%)$ in the Savannakhet Plain used chemical fertilizers for the wet-season (WS) crop and all used chemical fertilizers for the dry-season (DS) crop. The commonly used fertilizers were urea (46-00-00), ammonium phosphate (16-20-00), and compound fertilizers such as 16-08-08 (16\%) and 15-15-15 (4\%). The most common fertilizer brands used by Savannakhet farmers were Ox Brand from the Thai Central Chemical Public Company Limited, Rabbit Brand from the Chia Tai Company Limited, and Football Brand from an unidentified company in Vietnam. These were the brands with higher quality and price. Most farmers used fertilizers based on their financial capacity; only a few based their usage on technical requirements. Some farmers could not afford to apply fertilizers due to the high and fluctuating price. In many 
cases, the cost of applying additional fertilizers outweighed the additional return (see Chap. 10). In addition to applying chemical fertilizers, farmers in Savannakhet still applied animal manure to their rice fields before land preparation. The animal manure was sought from within the family and the village. Farmers applied as much as they could find as the number of animals had decreased and manure was increasingly scarce.

\section{Actors in the Supply Chain}

The fertilizer supply chain for Savannakhet Province is illustrated in Fig. 8.1. The fertilizers used by farmers in the province were mainly sourced from Thailand, Vietnam, and Taiwan. Most imports occurred through the border checkpoints at Savannakhet-Mukdahan (Thailand) and Dansavanh-Lao Bao (Vietnam), at either end of National Route 9 which traversed the province (see Fig. 5.1 in Chap. 5). The major types of supplier are discussed in turn.

(a) Individual agents. The individuals in Fig. 8.1 were villagers who acted as sales agents for a fertilizer company. They supplied a liquid organic fertilizer called Mabalap Mahalouy, supplied by the

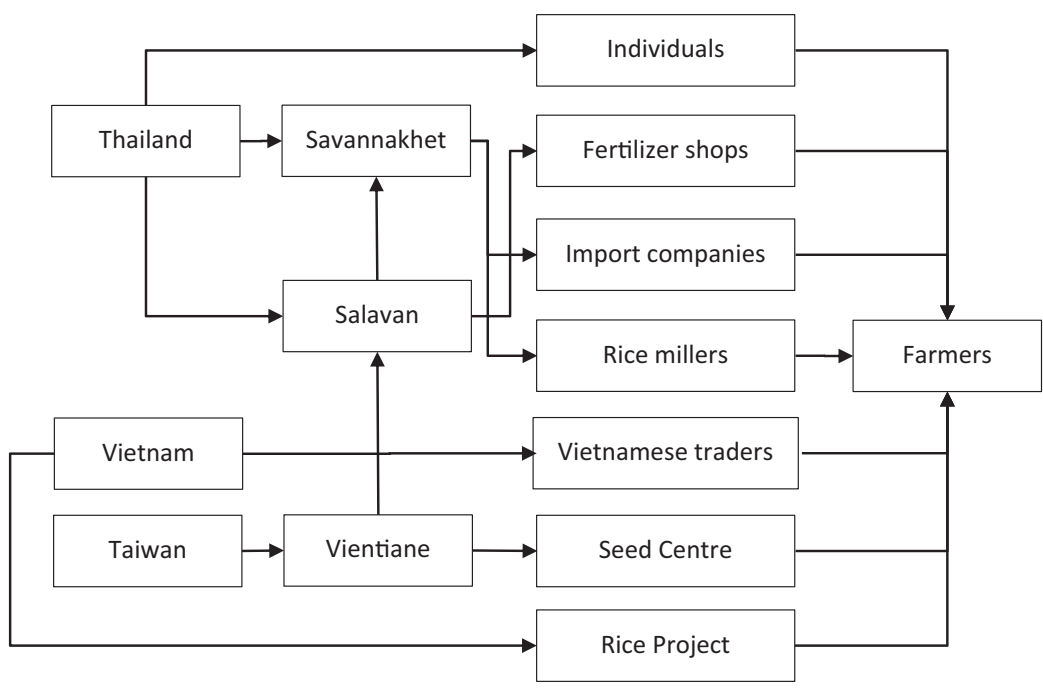

Fig. 8.1 Fertilizer supply chain for Savannakhet Province 
Lifestyles Company in Thailand. The concentrated fertilizer was to be mixed with water and sprayed onto the rice leaves every seven days. Farmers who had used this fertilizer said that rice production had improved as a result, though the response was slow compared to chemical fertilizers. The fertilizers came in a set of two bottles, each costing THB 580 (around LAK 150,000).

These individual agents also supplied chemical fertilizers, buying up stocks and storing them in their houses. The types of fertilizers supplied in this way were 15-15-15, 46-00-00, 16-20-00, and 16-8-8. Farmers could purchase directly from the individual. Payment could be made in cash or the fertilizer could be taken on credit. There was no interest charged and farmers could simply repay the credit after harvest.

(b) Import companies and fertilizer shops. These were not solely for selling fertilizers; their main activity was selling construction materials. However, they would have a corner of the shop devoted to fertilizers during the production season, mostly imported from Thailand. The same four types of fertilizers were sold-46-0-0, 15-15-15, 16-20-0, and 16-8-8. These distributors used to provide credit to farmers but, due to the low rate of repayment, only cash sales were now made. The import companies usually imported fertilizers directly, whereas the shops were supplied by mobile vendors who visited from time to time. These vendors could not be traced in the study and it was unclear how they imported their fertilizers.

(c) Rice millers. There were three rice millers supplying fertilizers to farmers in the study villages. The same four types were provided. The fertilizers were bought from a fertilizer shop in Kilometre-35 Village and some were imported from Salavan Province. Both cash and credit sales were made available to farmers. For credit sales, the miller would make a contract with the farmers which stated the total amount to be repaid, the due date, the form of repayment (cash or rice-if the latter the quantity was calculated based on the current rice price at the time of drawing up the contract), and the interest rate (typically $1.0-2.5 \%$ per month).

(d) Vietnamese traders. These traders played a significant role in the fertilizer supply chain. Though they did not come to Savannakhet intending to sell fertilizers, in 2008 they saw the potential for supplying fertilizers to farmers in Champhone District. They imported around 30-40 tons per year from Vietnam, all in the wet 
season around May, June, and July. It was unclear how they brought in the fertilizers. Farmers said that at the beginning of the production season the traders came to the village with a load of fertilizers in their truck and the farmers were free to select whatever fertilizer they wanted. They brought in three main types-46-0-0, 15-15-15, and 16-20-0. Although the price of the Vietnamese fertilizers was cheaper than fertilizers from Thailand, farmers claimed they had to use almost twice as much Vietnamese fertilizers to obtain the same yield as with Thai fertilizers.

The Vietnamese traders supplied fertilizers to farmers in the village on credit; once farmers had cash or after the harvest was completed, the traders would come back to the village to collect the money. Due to the generally high price of fertilizers, this form of credit was popular with farmers who were short of working capital. Despite the poorer quality of the fertilizers, farmers were attracted by the availability of credit and the saving on the time and cost of purchasing fertilizers in town.

(e) Thasano Seed Production Centre. The seed production centre at Thasano, under the Ministry of Agriculture and Forestry, was located on National Road 13 just west of Champhone District. The Centre worked with village heads to organize seed production groups of 20-30 farm households to which it provided fertilizers. These groups were established because the demand for improved seeds was exceeding the Centre's own production capacity. Participating farmers had to agree with the Centre and village head to comply with the seed production techniques and standards provided by the Centre. Once a farmer group was formed, a contract was developed between the group and the Centre. The contract stated clearly the seed production techniques or standards that the farmers had to follow, that the output had to be sold to the Centre, and that the Centre would not purchase seeds from farmers who did not follow the specified procedures.

The Centre supplied two types of fertilizers to the seed producing groups-chemical and bio-fertilizers. The chemical fertilizers included 46:00:00, 16:20:00, and 15.15.15. The Centre ordered these fertilizers as required from Siam Machinery Intertrade Company Limited, based in Thailand, with importation through the Dansavanh-Lao Bao border crossing. However, the Centre had received exemption from import duty because of its public role. 
The bio-fertilizers were supplied by Rfarm Company, with its head office in the capital and its factory located in Hin Hurb District, Vientiane Province. The Centre understood that the company imported fertilizers directly from Taiwan. However, further enquiries revealed that the company imports materials from Taiwan and then processes, repacks, and distributes the product in Laos.

(f) Rice Production Improvement Project. This project aimed to improve rice productivity for farmers and supply good rice variety for farmers who lack access to high-quality seed. The village head and the project coordinator collaborated closely in organizing farmer groups of 20 farmers each. The participants had to have at least 0.5 ha of paddy land, be hard-working farmers, and belong to a minority group that had less access to fertilizers and seeds. Once the farmer group was organized and the group committee assigned, the project supplied them with fertilizers of two types-15:15:15 and 46:00:00. The project imported fertilizers directly from Vietnam and stamped a Lao logo on the bags before supplying the farmers. One group of farmers received 50 bags of fertilizers-30 bags of 15:15:15 and 20 bags of 46:00:00. There was neither any charge to the farmer group nor any requirement to repay the cost at the end of the season. The fertilizer was only made available to farmer groups; farmers who were not members could benefit from this line of supply.

Table 8.2 shows the estimated annual volume of fertilizers imported by each of the above actors. The Thasano Seed Production Centre imported a large quantity but it was a single supplier and mainly supplied its own seed producers. The import companies and input supply shops were more

Table 8.2 Estimated annual imports of fertilizer per supplier

\begin{tabular}{lc}
\hline Supplier & Imports (tons/year) \\
\hline Vietnamese trader & 40 \\
Fertilizer shop & 5800 \\
Rice miller & 48 \\
Import company & 6175 \\
Seed production centre & 37,025 \\
\hline
\end{tabular}

Source: Based on interviews with suppliers 


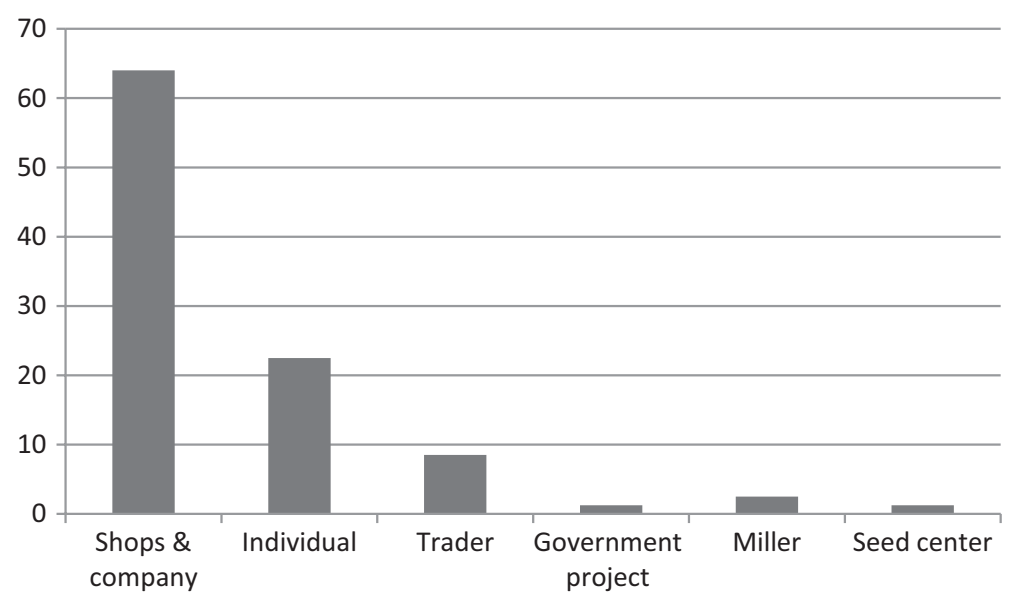

Fig. 8.2 Farmers' sources of fertilizer (\% of survey respondents)

numerous and handled about 6000 tons each, hence these were the main suppliers. The Vietnamese traders and rice millers each handled a smaller quantity, but the traders were important suppliers in some villages.

About two-thirds of the farmers surveyed obtained their fertilizers from shops and import companies (Fig. 8.2). The reason given was that these suppliers had lower prices. This was confirmed in interviews with the different suppliers. Exemptions from import duty helped to lower the price. About a third of farmers purchased fertilizers from individual agents in the village and/or visiting Vietnamese traders. Millers, the seed production centre, and the Rice Production Improvement Project each supplied only a small percentage of farmers.

\section{Fertilizer Transactions}

There were two forms of payment for fertilizers-cash and credit (Table 8.3). The vast majority of farmers producing rice primarily for commercial purposes paid in cash because the price was lower than under the credit system. In the latter case, the price incorporated an implicit interest rate that varied between suppliers. Farmers using credit (34\%) were those with limited capital during the production season, hence they had no choice but to pay the interest premium. These farmers stated that if they had available cash at the time of purchasing production inputs they 
Table 8.3 Incidence of farmers paying cash or using credit for fertilizer purchases, by type of supplier

\begin{tabular}{lcc}
\hline Supplier & $\begin{array}{l}\text { Farmers paying } \\
\text { cash (\%) }\end{array}$ & $\begin{array}{l}\text { Farmers using } \\
\text { credit (\%) }\end{array}$ \\
\hline Shop/import company & 60.0 & 4.0 \\
Individual agent & 5.5 & 17.0 \\
Vietnamese trader & 0.0 & 8.5 \\
Miller & 0.5 & 2.0 \\
Seed centre & 0.0 & 1.25 \\
Rice production project & 0.0 & 1.25 \\
\hline
\end{tabular}

Source: Farmer survey, 2012

Table 8.4 Comparison of fertilizer prices between cash payment and credit

\begin{tabular}{llll}
\hline $\begin{array}{l}\text { Type of } \\
\text { fertilizer }\end{array} \quad \begin{array}{l}\text { Cash price (kip/50 kg } \\
\text { bag) }\end{array}$ & $\begin{array}{l}\text { Credit price (kip/50 kg } \\
\text { bag) }\end{array}$ & $\begin{array}{l}\text { Difference (kip/50 kg } \\
\text { bag) }\end{array}$ \\
\hline $\begin{array}{l}\text { Thai brand (Ox Brand, Rabbit Brand) } \\
46-00-00 \quad 250,000\end{array}$ & 300,000 & \\
$15-15-15 \quad 300,000$ & 375,000 & 50,000 \\
Vietnamese brand (Football Brand) & & 75,000 \\
$46-00-00 \quad 150,000-175,000$ & 250,000 & $75,000-100,000$ \\
\hline
\end{tabular}

Source: Farmer survey, 2012

would prefer to pay up-front in cash. Among the suppliers, the village agents and Vietnamese traders were the most willing to supply fertilizers on credit. These traders were flexible and willing to negotiate the time of payment and to receive whatever amount the farmer could pay.

The cash and credit prices for selected types of fertilizers are shown in Table 8.4. One point to note is that urea from Thailand was up to twothirds more expensive than urea from Vietnam, presumably reflecting the quality differences reported by farmers. The table also shows variation in the implicit interest charge incorporated in the credit price. For Thai brand urea, supplied by shops and import companies, the premium was $20 \%$ and for Thai brand compound fertilizer (15-15-15) it was $25 \%$. Assuming six months until payment, the annualized interest rate was 40-50\%. However, for Vietnamese urea supplied by Vietnamese traders, the premium was $40-65 \%$, representing an annualized interest rate of $80-130 \%$. This higher rate probably reflected the greater flexibility of the Vietnamese traders in the payment time and amount.

Data were obtained on the margins between the purchasing and selling prices of different types of fertilizers for different suppliers (Table 8.5). 
Table 8.5 Marketing margins for fertilizer suppliers

\begin{tabular}{lccc}
\hline $\begin{array}{l}\text { Supplier and type of } \\
\text { fertilizer }\end{array}$ & $\begin{array}{c}\text { Purchase price } \\
(\text { LAK/kg) }\end{array}$ & $\begin{array}{c}\text { Selling price } \\
(\text { LAK/kg })\end{array}$ & $\begin{array}{l}\text { Margin } \\
(\%)\end{array}$ \\
\hline $\begin{array}{l}\text { Trader } \\
\text { 46-00-00 }\end{array}$ & & \\
15-15-15 & 4700 & 5900 & 25.5 \\
16-20-00 & 4400 & 4900 & 11.4 \\
Shop & 4400 & 4900 & 11.4 \\
$46-00-00$ & 4700 & 4900 & 4.3 \\
15-15-15 & 4800 & 4950 & 3.1 \\
$16-20-00$ & 4400 & 4500 & 2.3 \\
Import company & & & \\
$46-00-00$ & 4100 & 4200 & 2.4 \\
$15-15-15$ & 4300 & 4200 & 16.4 \\
16-20-00 & 3600 & 4200 & 18.8 \\
Miller & & & 20.0 \\
$46-00-00$ & 4800 & 5700 & 11.9 \\
$15-15-15$ & 5000 & 6000 & \\
$16-20-00$ & 4200 & 4700 & \\
\hline
\end{tabular}

The traders had the highest margins, up to $25 \%$ for urea, but this included the cost of delivery to the village. Millers also had high margins of around $20 \%$. The shops and import companies had relatively low margins of $2-4 \%$. The import companies purchased fertilizers 10-20\% more cheaply than the other suppliers and could also distribute at a lower price. Moreover, although the purchasing price of the three main fertilizers was different, this distributor sold them at the same price-LAK 4200 per $\mathrm{kg}$-which was up to $30 \%$ cheaper than other suppliers. When asked why the selling price was uniformly low, the distributor merely remarked that the price was sufficient to compensate for the purchase price.

\section{Constraints and Problems}

The survey highlighted some problems with the fertilizer supply chain, both for farmers and importers/distributors. The problems reported by farmers related to quality, capital, and price. The problems reported by suppliers related to documentation processes and bad debts.

Many farmers complained about the poor quality of the fertilizers they purchased. They said that the rice was slow to respond to some types of fertilizers. This was especially the case for Vietnamese fertilizers, while the Thai fertilizer was perceived to be of high quality. Some farmers mixed 
fertilizers from Vietnam with fertilizers from Thailand, which they said gave a better response. Access to financial resources was important to enable farmers to have fertilizers when they needed them most. The only financial support available was from the Agricultural Promotion Bank, but to qualify for a loan farmers had to form a group of 10-20 members and submit a production proposal to the Bank. Each member had to guarantee that every other member would repay their loan or else the group would be liable. Many farmer groups had failed to repay their loans. The only alternative for capital-scarce farmers was to take fertilizers on credit from Vietnamese traders and individual agents with much higher implicit interest rates, as shown above. Compounding these problems, the price of fertilizers was continually increasing, making it harder to purchase highquality fertilizers and reducing the incentive to apply optimal amounts.

Many importers complained about the documentation procedure for importing fertilizers. The complexity of this process led to higher import costs, pushing up the retail price encountered by farmers. Suppliers also commented on the low rate of repayment for fertilizer credit. Many had stopped providing credit as a result. Only the Vietnamese traders and some individual agents still provided credit, with very flexible repayment times and instalments. However, they offset their risks with higher marketing margins and very high implicit interest rates.

\section{The Seed Supply Chain}

\section{Origin and Uptake of Improved Varieties}

Though improved rice varieties had been introduced to Laos since 1960, in 1990 about $95 \%$ of the lowland WS rice crop was still based on traditional varieties (Inthapanya et al. 2006). From the 1990s, rice breeding and seed production stations were established and a succession of high-yielding glutinous varieties were selected and disseminated to the major ricegrowing areas in the Mekong Valley, with rapid uptake by farmers (see Chap. 6). At the time of this study, there were four active seed production centres, breeding and supplying improved varieties of rice throughout the country - three in Vientiane Capital, Napok, Phonengam, and Dondaeng, and one in Savannakhet, the Thasano Seed Production Centre mentioned earlier.

These centres produced a wide range of varieties with different attributes. Thasano produced ten varieties and about 50 tons of rice seeds per 
year. Farmers in Savannakhet also used varieties from Vientiane, including Thadokham (TDK) and Phonengam (PNG) varieties, and a variety from the Provincial Agriculture and Forestry Office (PAFO) (Homsavanh). Farmers also selected and conserved their own seeds.

In the survey, most farmers $(86 \%)$ reported using an improved variety in the WS, with $32 \%$ using TDK10, a relatively recent release, and $15 \%$ using PNG 3, a high-yielding, drought-tolerant variety released in 2005. All farmers used only improved varieties in the DS, including TDK10 (22\%), TDK5 (19\%), TDK8 (13\%), and PNG3 (8\%). It was noteworthy that the use of TDK5, a short-duration variety, increased in the DS.

\section{Actors in the Supply Chain}

The structure of the seed supply chain is shown in Fig. 8.3. The principal actors were the seed production centres shown on the left, multiplying up the first and second rounds ( $\mathrm{Rl}$ and $\mathrm{R} 2$ ) of the certified seed; the seed production groups, producing R2 and R3 seeds; the PAFO and the District Agriculture and Forestry Office (DAFO) that distributed the seed, along with millers and the Rice Production Improvement Project; and the farmers,

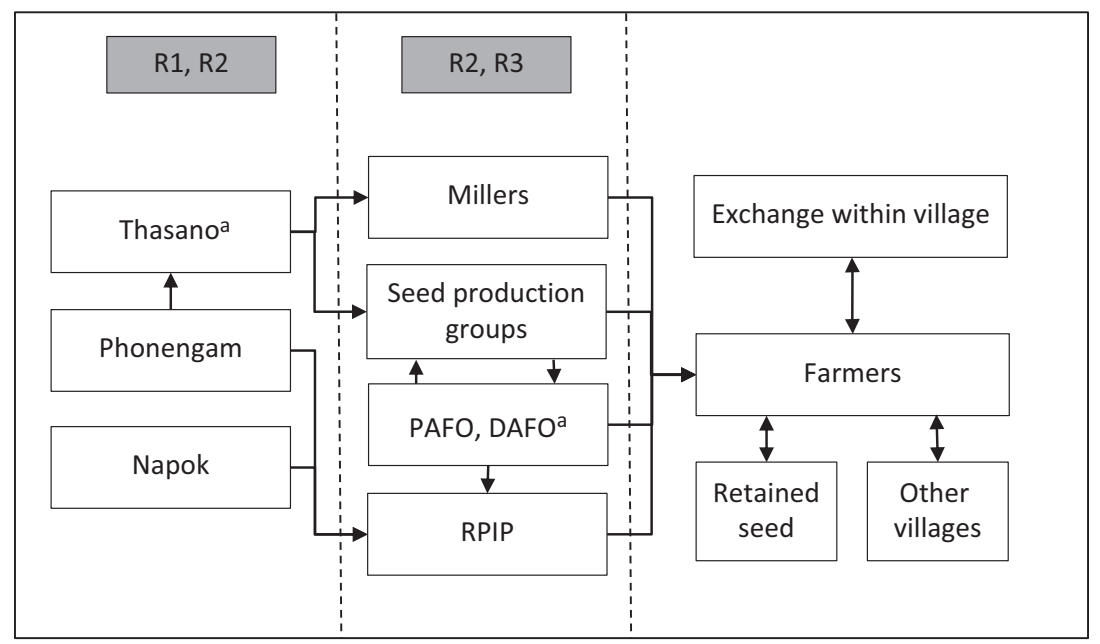

Fig. 8.3 The seed supply chain in Savannakhet. ${ }^{a}$ Thasano Centre and PAFO/ DAFO buy back seeds from the seed production groups at $10 \%$ above the market price for paddy rice 
who purchased the seed, selected and retained the seed for their own use, and exchanged the seed with other farmers within and outside their village.

(a) Seed production centres. These centres produced both Rl and R2 seeds. However, due to the increasing demand for seeds of improved varieties, Thasano was working with groups of farmers to multiply seeds. A farmer group consisted of around 20 farmers who made an agreement with the Centre to produce and supply seeds. Centre staff visited the farmers' fields from time to time to ensure that they were meeting the required standards. If the farmers' seed production met the standards for certification, the Centre or the PAFO bought the seed at a premium price; otherwise farmers had to sell it in the market as normal eating rice.

(b) Seed production groups. The farmer seed production groups were organized under the supervision of the Thasano Centre and the Rice Production Improvement Project, run by the PAFO. These farmers produced either R2 or R3 seed to supply the Centre and the project. Thasano and the PAFO paid a $10 \%$ premium for seeds produced according to the requirements for certification. The farmer groups were also allowed to sell seeds directly to farmers.

(c) Rice Production Improvement Project (RPIP), PAFO, and DAFO. The RPIP was being implemented by the PAFO and DAFOs with financial support from the World Bank. One of its goals was to help poor and minority farmers to get access to good-quality seed. The project was working with 33 farmer groups and 615 households, including eight groups in Champhone District. The project worked with the village head to organize the farmer group. One bag of R2 seed was provided free to each household. The PAFO/DAFO then bought the seed produced by the farmer group at a $10 \%$ premium. This seed still needed further purification before selling commercially.

(d) Rice millers. Rice millers supplied seeds to farmers in the same way as they supplied fertilizers. The millers bought seeds from the Thasano Seed Production Centre and sold it to farmers at LAK 2000 per $\mathrm{kg}$. The farmers could pay for the seeds immediately in cash or after harvest in cash or rice (calculated from the current rice price).

(e) Farmers. Farmers sourced seeds from many different distributors depending on their circumstances, including the seed production 
Table 8.6 Sources of seed reported by survey farmers

\begin{tabular}{lcc}
\hline Source & No. of respondents & \% of respondents \\
\hline Seed production centre & 40 & 17.5 \\
Rice Production Improvement Project & 45 & 19.7 \\
Farmers' seed production group & 42 & 18.4 \\
Miller & 4 & 1.8 \\
Within village & 93 & 40.8 \\
Other village & 4 & 1.8 \\
Total & 228 & 100.0 \\
\hline
\end{tabular}

Source: Household survey, March 2012

centre (18\%), the RPIP (20\%), and seed production groups (18\%) (Table 8.6). However, the most common source was other farmers within the village (41\%). Farmers reported that they observed each other's rice fields and if someone had a variety that provided higher yield and better quality, they would exchange the seed with that farmer. Observing neighbouring rice fields was a simple technique preferred by farmers to find a suitable new variety because if the variety performed well in the neighbour's field, in their experience it was likely to be well adapted to his or her own field (Fig. 8.4). This cultural practice was of long-standing and occurred throughout Laos, providing the basis for technical change. The village communities were relatively small and homogenous so that everyone knew each other, hence it was easier for farmers to observe fields and exchange rice varieties with their neighbours than to search for improved varieties independently. By this means, the improved varieties developed from the 1990s have spread rapidly in lowland areas.

The price paid by farmers for seeds from different sources is compared with the estimated cost of seed production in Table 8.7. The seed production centres had a higher cost of production and a higher selling price (LAK 5000-6000 per kg). The higher price reflected both their higher costs and significantly higher margins (66-100\%). The farmer groups produced seeds at a lower cost and sold to other farmers at a lower price, with a margin of $25-50 \%$. However, their margin in selling back to the government agencies was only $25 \%$ or less. The millers also sold seeds more cheaply and with a lower margin. 


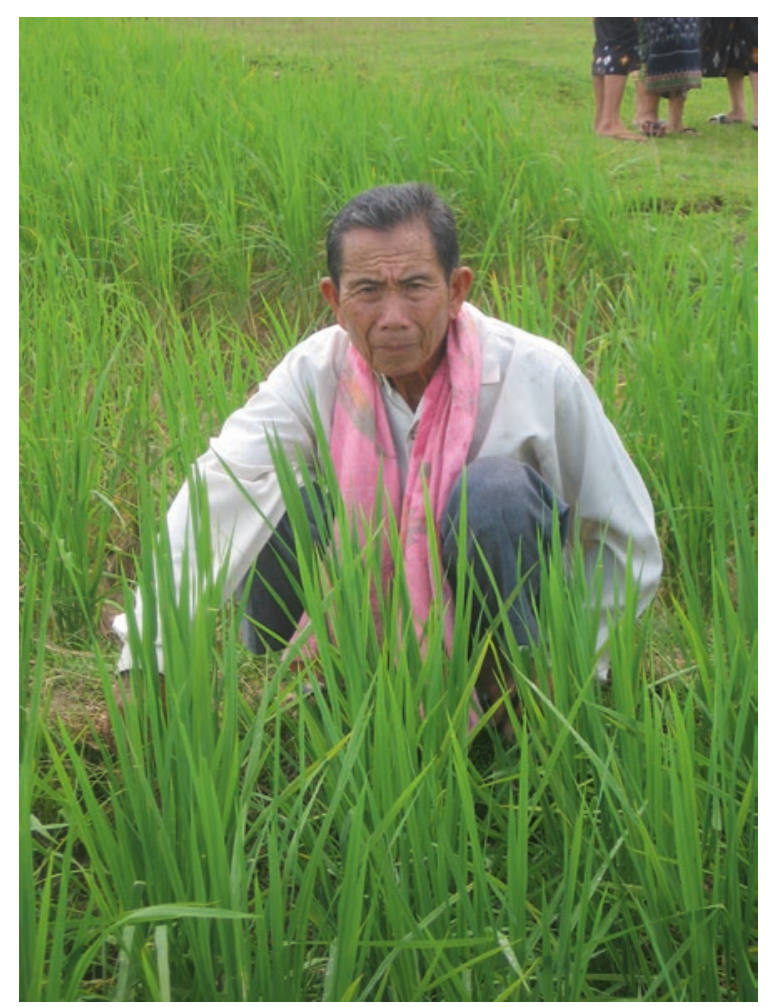

Fig. 8.4 Farmer in paddy field planted with improved variety in Savannakhet Province. (Source: Rob Cramb)

\section{Problems and Constraints}

Several problems were identified in the course of the survey. Farmers reported that the seed they bought from the main suppliers was mostly impure. This suggests that the seed production process was not properly monitored and so there was still a problem of mixing seeds of different varieties. This was compounded by the absence of a proper seed certification system to provide information on whether the seed the farmer bought was in compliance with seed production standards. Such a seed certification system would solve the problem of impure seeds and farmers would have more confidence in the quality of the seed they purchased. 
Table 8.7 Production costs and selling prices of rice seeds by source

\begin{tabular}{llll}
\hline Seed producer & $\begin{array}{l}\text { Production/purchase cost } \\
(\text { LAK/kg) }\end{array}$ & $\begin{array}{l}\text { Selling price } \\
(\text { LAK/kg) }\end{array}$ & $\begin{array}{l}\text { Margin } \\
(\%)\end{array}$ \\
\hline $\begin{array}{l}\text { Thasano Seed Production } \\
\text { Centre }\end{array}$ & 3000 & $5000-6000$ & $66-100$ \\
$\begin{array}{l}\text { Napok Seed Production } \\
\text { Centre }\end{array}$ & 3000 & 5000 & 66 \\
$\begin{array}{l}\text { Farmer group (selling to } \\
\text { farmers) }\end{array}$ & 2000 & $2500-3000$ & $25-50$ \\
$\begin{array}{l}\text { Farmer group (selling to } \\
\text { government) }\end{array}$ & 2000 & $2000-2500^{\mathrm{a}}$ & $0-25$ \\
Millers & 2000 & $2500-3000$ & $25-50$ \\
\hline
\end{tabular}

Source: Field survey, March 2012

${ }^{a}$ Thasano Centre and PAFO/DAFO buy back seeds from the seed production groups at $10 \%$ above the market price for paddy rice

Farmers also felt that there was a lack of varieties for specific soil and climatic conditions (e.g., infertile sandy soils, drought, and flooding). They wanted seed that was clearly labelled regarding its suitability to specific environments (e.g., flood-tolerant). However, the four seed production centres had not yet released such site-specific varieties, focusing rather on varieties that would do reasonably well in a range of environments. Farmers also reported that the available varieties were not resistant to pests and diseases, restricting productivity in some areas.

\section{Conclusion}

Farmers in Champhone District had mostly adopted the seed-fertilizer technology that formed the basis of increased yields and productivity in Asian rice farming (Chaps. 1 and 6). Mechanization of land preparation through the use of hand tractors was also widespread. Many had also intensified their cropping system, using irrigation to cultivate a DS crop as well as the traditional rainfed WS crop. However, the productivity and profitability of rice farming remained low. Constraints to the supply of seeds and fertilizers can explain part of this dilemma.

Farmers used mostly improved varieties for the WS crop and entirely so for the DS crop. These were mostly glutinous varieties, incorporating introductions from the International Rice Research Institute (IRRI) and Thailand with Lao genetic material, to produce higher yields in a range of adverse 
environments. They had been progressively released since the 1990s and were rapidly adopted and disseminated. Just over a third of Champhone farmers $(37 \%)$ sourced their seed from the formal public-sector supply chain, including seed production centres, PAFO, DAFO, and a governmentimplemented rice development project. The private sector played little role, apart from some millers who included seed in their advance of inputs to selected surplus-producing farmers. Most farmers (61\%) obtained seed from other farmers, including $18 \%$ who bought from a seed production group, set up by the seed production centres to accelerate the multiplication of seeds, and $43 \%$ who exchanged the seed with their neighbours, after observing the performance of different varieties in the field, and then selected and retained the seed for their subsequent use. In this way, they gained access to the improved varieties, though probably with some deterioration in seed quality and hence yield (Diaz et al. 1998). Indeed, the main problems identified concerned the lack of proper seed certification, the supply of impure seeds, lack of varieties for specific soil and climatic conditions, and lack of varieties with resistance to the prevalent pests and diseases.

Farmers also used various types of fertilizers in their rice production, including chemical fertilizers from Thailand and Vietnam, organic fertilizers, and animal manure. While the increasingly limited supply of animal manure was sourced from neighbours in the village, the manufactured fertilizers were sourced from a range of mainly privatesector distributors, including import companies, input supply shops, mobile traders, individual villagers acting as agents, and rice millers. In addition, the government seed production centre and the Rice Production Improvement Project supplied fertilizers to farmers participating in their activities. Most of these suppliers provided chemical fertilizers, including urea, ammonium phosphate, and compound nitrogen-phosphoruspotassium (NPK) fertilizers; only a few provided organic fertilizers. The most important suppliers were the import companies and shops, who preferred cash payment at the time of purchase. In contrast, the traders mainly supplied fertilizers in the village on credit, to be repaid soon after harvest, with an implicit interest charge of $50-100 \%$ p.a. incorporated in the price. Farmers with limited capital were more likely to use this credit system. The major problems identified in this fertilizer supply chain were the poor quality of especially the Vietnamese product, the lack of financial resources to buy sufficient fertilizers, and the increasing price of fertilizers.

There is clearly scope for policy intervention to improve the supply and use of productive inputs for more intensive rice production. Further 
investment in the rice breeding and seed production centres may be needed to develop suitable varieties for the range of rice environments encountered by farmers and to improve the quality of the seed supplied. This needs to be accompanied by an official seed certification system to ensure farmers have access to high-quality seeds and information about varieties suited to their local situations. While the increasing price of fertilizers was clearly a constraint, marketing margins were quite low, implying a competitive in-country distribution system. Intervening to control or subsidize the price of fertilizers can be a costly and administratively cumbersome policy and is unlikely to be effective. The government could, however, take action to further simplify the import process, which would help reduce costs that are passed on to farmers, to increase the capacity to monitor and enforce fertilizer quality standards, and provide more siteand variety-specific information to farmers regarding optimal fertilizer use.

\section{REFERENCES}

Diaz, C., Hossain, M., Merca, S., and Mew, T., 1998. Seed quality and effect on rice yield: findings from farmer participatory experiments in Central Luzon, Philippines. Philippines Journal of Crop Science 23(2): 111-119.

Inthapanya, P., Boualaphanh, C., Hatsadong, and Schiller, J. M., 2006. The history of lowland rice variety improvement in Laos. In J. M. Schiller, M. B. Chanphengxay, B. Linquist, and S. Appa Rao, eds., Rice in Laos, pp. 325-348. Los Baños, Philippines: International Rice Research Institute. 
Open Access This chapter is licensed under the terms of the Creative Commons Attribution 4.0 International License (http://creativecommons.org/licenses/ by $/ 4.0 /)$, which permits use, sharing, adaptation, distribution and reproduction in any medium or format, as long as you give appropriate credit to the original author(s) and the source, provide a link to the Creative Commons licence and indicate if changes were made.

The images or other third party material in this chapter are included in the chapter's Creative Commons licence, unless indicated otherwise in a credit line to the material. If material is not included in the chapter's Creative Commons licence and your intended use is not permitted by statutory regulation or exceeds the permitted use, you will need to obtain permission directly from the copyright holder.

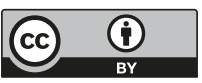

